\title{
Intrauterine Adhesions (IUAs) or Asherman's Syndrome (AS) and the Stem Cells Treatment: A Systemic Review and Meta-Analysis
}

\author{
Sichen Zhang1,2, Ying Mao1, Xiaodong Zhao', Huiwen Zhang',3, Min Ma',3, Xingbo Long2,3, \\ Shaowei Wang1,2* \\ ${ }^{1}$ Department of Gynecology and Obstetrics, Beijing Hospital, National Center of Gerontology, Institute of Geriatric Medicine, \\ Chinese Academy of Medical Sciences, Beijing, China \\ ${ }^{2}$ Peking Union Medical College, Chinese Academy of Medical Sciences, Santiao, Beijing, China \\ ${ }^{3}$ National Cancer Center/Cancer Hospital, Beijing, China \\ Email: sichen0622@sina.com, maoying100@sina.com, sparkling8027@sina.com, zhanghuiwen526@163.com, \\ minmascu@163.com,1021535851@qq.com, *w_sw999@163.com
}

How to cite this paper: Zhang, S.C., Mao, Y., Zhao, X.D., Zhang, H.W., Ma, M., Long, X.B. and Wang, S.W. (2021) Intrauterine Adhesions (IUAs) or Asherman's Syndrome (AS) and the Stem Cells Treatment: A Systemic Review and Meta-Analysis. Journal of Biosciences and Medicines, 9, 105-118. https://doi.org/10.4236/jbm.2021.91009

Received: December 30, 2020

Accepted: January 25, 2021

Published: January 28, 2021

Copyright $\odot 2021$ by author(s) and Scientific Research Publishing Inc. This work is licensed under the Creative Commons Attribution International License (CC BY 4.0).

http://creativecommons.org/licenses/by/4.0/

(c) (i) Open Access

\begin{abstract}
Background: Intrauterine Adhesions (IUAs) or Asherman's Syndrome (AS) usually contains symptoms such as decreased menstrual flow or even amenorrhea, chronic pelvic pain, recurrent abortion and infertility. The current treatment of IUAs includes hysteroscopic adhesiolysis, oral hormone and biological barriers, but each of them has limitation. Stem cell therapy may be an expanding field seeking for therapy in IUAs. Objective: We will discuss current advances in stem cell therapy as a treatment for endometrial pathophysiology. Materials and Methods: We search on PubMed, Embase and Cochrane library and select several keywords on researches, then review the cell biology theories and animal experiments, finally do meta-analysis in human clinical trials. Results: 77 articles on PubMed, 71 articles on Embase and 17 articles on Cochrane Library, as a result, 37 articles are included under the criteria, which are intrauterine adhesions (IUAs), Asherman's Syndrome (AS), cell therapy, stem cells, bone marrow stem cells, clinical trials, recent 10 years and human or animal experiments. The included criteria: original articles, cohort study, case control study, animal experiments, human clinical trials, high quality, 10 years recent. The excluded articles are case reports, meeting reports, low quality or more than 10 years ago. Conclusion: Stem cell may be a new therapeutic schedule for IUAs in the future clinical treatment, but it is necessary to compare it with traditional therapy such as oral hormone, also the development of random clinical tests should proceed. For clinical treatment on IUAs, stem cells could be a new choice.
\end{abstract}




\section{Keywords}

Intrauterine Adhesions IUA, Asherman's Syndrome, Stem Cells, Therapy, Infertility, Meta-Analysis

\section{Introduction}

Intrauterine Adhesions (IUAs) or Asherman's Syndrome (AS) is common caused by inflammatory or trauma damaging the endometrial basal layer after delivery or surgery [1] [2] [3]. The epidemiology of IUAs is unclear now, however, some researchers have reported that approximately 19\% amongst women suffering miscarriage and being prospectively assessed by hysteroscopy within 1 year [4]. In addition, about $70 \%$ of patients with severe Asherman's Syndrome had history of instrumentation such as aspirator during the postpartum period [5], whereas approximately $80 \%$ - 90\% patients with mild Asherman's Syndrome had similar procedures experienced at the first trimester. Furthermore, amongst women surgically treated for retained products of conception and evaluated hysteroscopy afterwards, the overall incidence of IUAs varies widely between 6 and $22 \%$ [6] [7].

The typical symptoms of IUAs or AS include decreased menstrual flow or amenorrhea, chronic pelvic pain, recurrent abortion and infertility [2] [8] [9]. However, the exact pathophysiologic origin of IUAs is still unclear. With expanded clinical awareness and availability of diagnostic testing, the frequency of diagnosis of IUAs has increased. Generally, the diagnosis of intrauterine adhesions depends on symptoms like menstruation and fertility and test such as ultrasound, Magnetic Resonance Imaging (MRI), Hysterosalpingography (HSG) and hysteroscopy [3]. Under a few of decades exploring and practice, the clinician recommended hysteroscopy as the golden standard of diagnosis by following the European Society of Gynecological Endoscopy (ESGE) publish the guidelines of diagnosis in 2016 [4].

In addition, the classification of IUAs is various in different areas, but no one is accepted universally, however, each of them is based on the grade of European Society for Hysteroscopy (ESH) in 1989 [4] [9] and American Fertility Society (AFS) in 1988 [1].

Currently, the therapeutic methods of IUAs include hysteroscopic adhesiolysis, oral hormone and biological barriers [10]. Primarily, severe forms may require multiple hysteroscopic adhesiolysis to achieve a satisfactory anatomical and functional result. Unfortunately, the recurrent rate of IUAs after hysteroscopy therapy is high [9] [10]. Then, estrogen supplementation is commonly given postoperatively to stimulate endometrial growth; yet, there is no standard dosage length or regimen or explanation of risk of stimulating breast and ovarian tumor [11] [12]. At last, using intrauterine barriers such as balloons, catheters and other intrauterine devices which may keep the uterine walls apart from 
adhesiolysis to reduce adhesion recurrence are frequently employed [13] [14]. Whereas, 2010 American Association of Gynecologic Laparoscopists (AAGL) Practice Guidelines do not support use of antibiotic therapy before, during or after surgical management of IUAs because of increasing risks of infection [4].

In recent year, stem cell therapy [15] is an expanding field that seeks for alleviating numerous diseases involving malignant tumor, fibrosis, wound repair and inflammation. In addition, currently, cell bio-therapeutics for AS employ numerous sources of stromal and hematopoietic cell populations, including menstrual blood derived stromal cells (MenSCs), Umbilical Cord (UC) derived Mesenchymal Stromal Cells (MSCs), Bone Marrow derived Mononuclear Cells (BMMNCs) and peripheral blood derived mobilized populations. Thus, we aim to conclude stem cell therapy and IUAs or AS association in animal models and human clinical trials [16]. However, the problems of stem cells therapy like ethic, immune reaction or even risks of tumorigenesis limit it application in clinic, also, unknown mechanism, like gene regulation, protein modulation or paracrine effects should be explored and confirmed by future and it can be a new irritation for researchers.

In this article, we will discuss current advances in stem cell therapy as a treatment for intrauterine adhesions (IUAs) or Asherman's Syndrome (AS).

\section{Materials and Methods}

We search on PubMed, Embase and Cochrane library and select several keywords on researches including: intrauterine adhesions (IUAs), Asherman's Syndrome (AS), cell therapy, stem cells, bone marrow stem cells, clinical trials, recent 10 years and human or animal experiments. The included criteria: original articles, cohort study, case control study, animal experiments, human clinical trials, high quality, 10 years recent. In addition, the excluded criteria: case reports, meeting reports, low quality, more than 10 years ago.

Each article abstraction was performed using a standardized form; which included study characteristics such as year, author, area, type of study. Also each study should be scored under the scoring system like NOS (Newcastle-Ottawa quality assessment scale), Jadad, CASPin and iCAHE.

All the researches on human clinical trials are single-arm trials, and the data are extracted from text, tables, or figures. We conclude them and do the meta-analysis, all the differences in continuous outcomes using mean, weight mean difference (WMD) and sample size for each group, meanwhile Binary outcome is expressed as Odds Ratio (OR) and 95\% Confidence Interval (CI). Hozo formula was used to convert data expressed as median and range. Statistical analysis was performed using Meta-Analyst.

\section{Results}

Depending on those search strategies, we found about 77 articles on PubMed, 71 articles on Embase and 17 articles on Cochrane Library. As a result, 37 articles 
are included under the criteria, which are in details: clinical treatment 4, molecular 8 , guideline 3 , review article 7 , stem cells application 15 (animal 10, human 5). The search process is below as the Figure 1 and Table 1 illustrates the scores and quality of the articles.

\subsection{Molecular Experiments for Stem Cell and IUAs}

Multiple studies show that the stem cells may improve the outcomes of injuring diseases [17] [18], but it is still unclear that whether stem cells transplantation can be used as a therapy for IUAs. Nesrine [19] et al. Investigated the Transforming Growth Factors- $\beta$ (TGF- $\beta$ ), Tumor Necrosis Factor- $\alpha$ (TNF- $\alpha$ ) and Vascular Endothelial Growth Factor (VEGF) are significant decreased in extracellular vesicles derived from human umbilical cord mesenchymal stem cells (UCMSCs-EVs) alone or combined with estrogen therapeutic groups. Also, they reported that mesenchymal stem cells (MSCs) play a significant role in repairing injured tissues, which through the secretion of a wide range of paracrine factors. In addition, bone marrow stem cells (BMSCs) have been hypothesized to be important for endometrial regeneration and repair. In addition, a great deal of studies reported that endometrial stem cells could contribute to endometrial repairing physiologically, which may be crucial for the treatment of IUAs. An increasing number of evidences have proposed that stem cells play a key role in developing the therapeutic strategies for IUAs, although the molecular mechanism has not been acknowledged.

Recently, some researchers [20] [21] devote to explore the hypothesis and evidence of stem cells repairing in IUAs. Typically, Estrogen Receptor $\alpha(\operatorname{ER} \alpha)$ is able to effectively promote BMSC proliferation and migration via Stromal Derived Factor/Chemokine Receptor type 4 (SDF-1/CXCR-4) according to Zhou et al. [22]. They point out that the upregulation of anti-inflammatory cytokines (base Fibroblast Growth Factor, bFGF and Interleukin, IL6) and the droppedregulation of pro-inflammatory cytokines after BMSCs transplantation may stimulate proliferation endometrial cell and exert an inhibitory action on endometrial

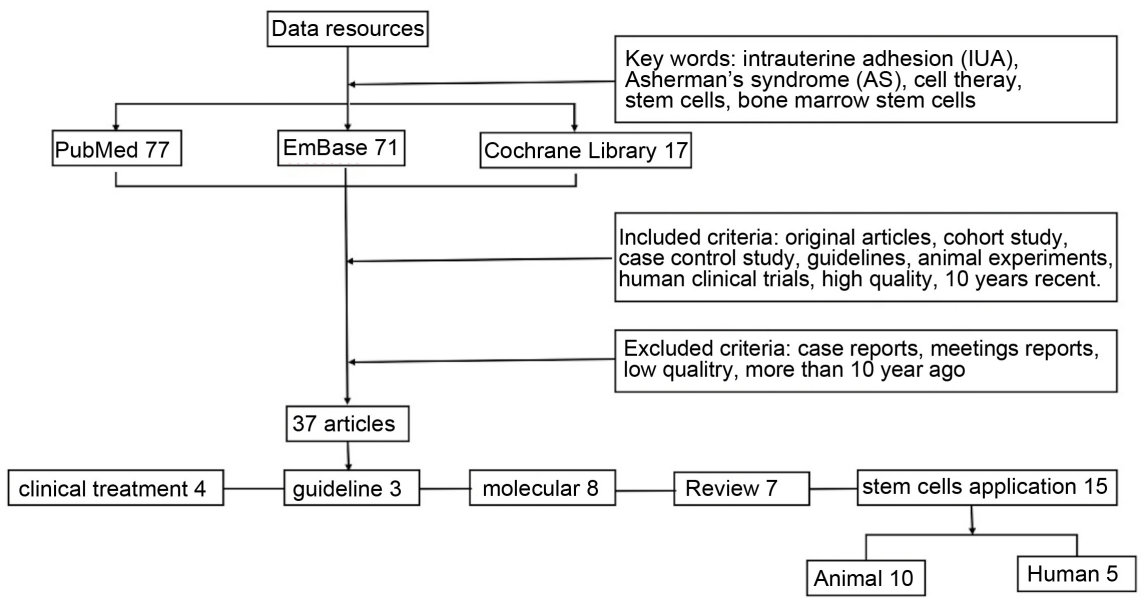

Figure 1. Research process. 
Table 1. Summary of researches.

\begin{tabular}{|c|c|c|c|c|c|c|c|}
\hline No. & Title & Author & Year & Type & Tools & Scores & Quality \\
\hline 1 & $\begin{array}{l}\text { Effectiveness of estrogen treatment before } \\
\text { transcervical resection of adhesions on } \\
\text { moderate and severe uterine } \\
\text { adhesion patients }\end{array}$ & Ai-Zhen Liu & 2016 & case-cohort & NOS & 7 & high \\
\hline 2 & $\begin{array}{l}\text { Prevalence of intrauterine adhesions after } \\
\text { the application of hyaluronic acid gel after } \\
\text { dilatation and curettage in women with at } \\
\text { least one previous curettage: short-term } \\
\text { outcomes of a multicenter, prospective } \\
\text { randomized controlled trial }\end{array}$ & $\begin{array}{l}\text { Angelo B. } \\
\text { Hooker, M.D }\end{array}$ & 2017 & RCT & Jadad & 5 & high \\
\hline 3 & $\begin{array}{l}\text { The incidence of post-operative adhesion } \\
\text { following transection of uterine septum: a } \\
\text { cohort study comparing three } \\
\text { different adjuvant therapies }\end{array}$ & Xiao Yu & 2016 & cohort & NOS & 6 & high \\
\hline 4 & $\begin{array}{l}\text { The management of Asherman syndrome: } \\
\text { a review of literature }\end{array}$ & $\begin{array}{l}\text { Alessandro } \\
\text { Conforti }\end{array}$ & 2013 & review & CASPin & 7 & moderate \\
\hline 5 & $\begin{array}{l}\text { Transdermal estrogen gel and oral aspirin } \\
\text { combination therapy improves fertility } \\
\text { prognosis via the promotion of endometrial } \\
\text { receptivity in moderate to severe } \\
\text { intrauterine adhesion }\end{array}$ & Yuguang Chi & 2017 & RCT & Jadad & 5 & high \\
\hline 6 & $\begin{array}{l}\text { AAGL Practice Report: Practice Guidelines } \\
\text { for Management of Intrauterine Synechiae }\end{array}$ & AAGL & 2009 & $\begin{array}{l}\text { clinical } \\
\text { practical } \\
\text { guideline }\end{array}$ & $\begin{array}{l}\text { iCAHE } \\
\text { guideline } \\
\text { quality } \\
\text { checklist }\end{array}$ & 11 & high \\
\hline 7 & $\begin{array}{l}\text { AAGL Practice Report: Practice Guidelines } \\
\text { on Intrauterine Adhesions Developed in } \\
\text { Collaboration With the European Society of } \\
\text { Gynaecological Endoscopy (ESGE) }\end{array}$ & AAGL & 2016 & $\begin{array}{l}\text { clinical } \\
\text { practical } \\
\text { guideline }\end{array}$ & $\begin{array}{l}\text { iCAHE } \\
\text { guideline } \\
\text { quality } \\
\text { checklist }\end{array}$ & 11 & high \\
\hline 8 & Review of Intrauterine Adhesions & $\begin{array}{l}\text { Rebecca } \\
\text { Deans }\end{array}$ & 2010 & review & CASPin & 8 & high \\
\hline 9 & $\begin{array}{l}\text { Abnormal expression of fibrosis markers, } \\
\text { estrogen receptor } \alpha \text { and stromal derived } \\
\text { factor- } 1 / \text { chemokine (C-X-C motif) } \\
\text { receptor- } 4 \text { axis in intrauterine adhesions }\end{array}$ & QIN ZHOU & 2018 & basic research & ARRIVE & 15 & moderate \\
\hline 10 & $\begin{array}{l}\text { Elevated NF- } \mathrm{kB} \text { signaling in Asherman } \\
\text { syndrome patients and animal models }\end{array}$ & $\begin{array}{l}\text { Xiangzhen } \\
\text { Wang }\end{array}$ & 2017 & basic research & ARRIVE & 16 & moderate \\
\hline 11 & $\begin{array}{l}\text { Molecular implication of ADAM-15 } \\
\text { and } 17 \text { in intrauterine adhesions }\end{array}$ & Dan Liu & 2013 & basic research & ARRIVE & 17 & high \\
\hline 12 & $\begin{array}{l}\text { Role of Transforming Growth Factor- } \beta 1 \\
\text { and Smads Signaling Pathway in } \\
\text { Intrauterine Adhesion }\end{array}$ & Umme Salma & 2016 & $\begin{array}{l}\text { basicl } \\
\text { research }\end{array}$ & ARRIVE & 18 & high \\
\hline 13 & $\begin{array}{l}\text { The Overexpression of TGF- } \beta \text { and CCN2 in } \\
\text { Intrauterine Adhesions Involves the NF- } \kappa \mathrm{B} \\
\text { Signaling Pathway }\end{array}$ & Xiang Xue & 2015 & $\begin{array}{l}\text { basicl } \\
\text { research }\end{array}$ & ARRIVE & 17 & high \\
\hline
\end{tabular}




\section{Continued}

The expression of marker for endometrial

14 stem cell and fibrosis was increased in intrauterine adhesious

A 10-year Review of the Clinical Presentation and Treatment Outcome of Asherman's Syndrome at a Center with Limited Resources

Systemic administration of bone

16 marrow-derived cells leads to better uterine engraftment than use of uterine-derived cells or local injection

A comprehensive review of Asherman's syndrome: causes, symptoms and treatment options

18 Cellular therapies for the endometrium

Efficacy and Safety of Hyaluronic Acid Gel for

19 the Prevention of Intrauterine Adhesion: A Meta-Analysis of Randomized Clinical Trials

Intrauterine adhesion prevention after

20 hysteroscopy: a systematic review and meta-analysis

Meta-analysis of the use of amniotic membrane to prevent recurrence of intrauterine adhesion after hysteroscopic adhesiolysis

22 Endometrial reconstruction from stem cells

CXCL12 Promotes Stem Cell Recruitment 23 and Uterine Repair after Injury in Asherman's Syndrome

Application of Bone Marrow-Derived

24 Mesenchymal Stem Cells in the Treatment of Intrauterine Adhesions in Rats

Feasibility analysis of treating severe intrauterine adhesions by transplanting menstrual blood-derived stem cells

Human amniotic mesenchymal stromal cell transplantation improves endometrial regeneration in rodent models of intrauterine adhesions

Human mesenchymal stem cell-derived extracellular vesicles/estrogen combined 27 therapy safely ameliorates experimentally induced intrauterine adhesions in a female rat model
Jianguo $\mathrm{Hu}$

201

basic research

ARRIVE

17

high

IU Takai

review

CASPin

high

$\begin{array}{llllll}\text { Ying Liu } & 2017 & \text { review } & \text { CASPin } & 7 & \text { moderate }\end{array}$

Christina A. Salazar

review

CASPin

9

high

Suzanna Queckböner

2018

review

CASPin

6

moderate

Huafang Liu

2017

review

CASPin

10

high

Mae Wu

Healy

2016

review

CASPin

8

high

Fei Zheng

2018

review

CASPin

8

high

Caroline E. Gargett, Ph.D

2012

review

CASPin

6

moderate

Gulcin Sahin 2017

animal Ersoy

research

ARRIVE

17

high

Jianmei

2016

animal

research

ARRIVE

16

moderate

SHEN-XIA

ZHENG

2016

animal

research

ARRIVE

18

high

LU GAN

2017

animal

research

ARRIVE

17

high

Nesrine 2018
ARRIVE

17

high

\section{animal} research 


\section{Continued} novel therapeutic agents in regeneration of induced endometrial fibrosis in experimental rats

Vitamin C plus hydrogel facilitates bone

marrow stromal cell-mediated endometrium regeneration in rats

Bone Marrow-Derived Stem Cell (BMDSC)

30 Transplantation Improves Fertility in a Murine Model of Asherman's Syndrome

Effect of stem cell application on Asherman syndrome, an experimental rat model

Platelet-rich plasma improves therapeutic effects of menstrual blood-derived stromal cells in rat model of intrauterine adhesion

Autologous menstrual blood-derived

33 stromal cells transplantation for severe Asherman's syndrome

Autologous stem cell transplantation in

34 refractory Asherman's syndrome:

A novel cell based therapy

Autologous cell therapy with CD1331 bone marrow-derived stem cells for refractory Asherman's syndrome and endometrial atrophy: a pilot cohort study

Transplantation of collagen scaffold with autologous bone marrow mononuclear cells promotes functional endometrium reconstruction via down regulating $\Delta \mathrm{Np} 63$ expressionin Asherman's syndrome

Allogeneic cell therapy using umbilical cord MSCs on collagen scaffolds for patients with recurrent uterine adhesion: a phase I clinical trial $\begin{array}{lrrrr}\text { Dina Sabry } 2017 \quad \begin{array}{r}\text { animal } \\ \text { research }\end{array} & \text { ARRIVE } & 16 & \text { moderate }\end{array}$

$\begin{array}{lllll}\text { Huan Yang } 2017 & \begin{array}{r}\text { animal } \\ \text { research }\end{array} & \text { ARRIVE } & 17 & \text { high }\end{array}$

$\begin{array}{cccccc}\begin{array}{c}\text { Feryal } \\ \text { Alawadhi }\end{array} & 2014 & \begin{array}{c}\text { animal } \\ \text { research }\end{array} & \text { ARRIVE } & 18 & \text { high } \\ \text { Sevtap Kilic } & 2014 & \begin{array}{r}\text { animal } \\ \text { research }\end{array} & \text { ARRIVE } & 17 & \text { high }\end{array}$

$\begin{array}{lllll}\text { Siwen Zhang } & 2019 & \text { animal } & \text { ARRIVE } & 15\end{array}$

$\begin{array}{llllll}\text { Jichun Tan } & 2016 & \text { cohort } & \text { NOS } & 8 & \text { high }\end{array}$

$\begin{array}{llllll}\text { Neeta Singh } & 2014 & \text { cohort } & \text { NOS } & 8 & \text { high }\end{array}$

$\begin{array}{cllll}\text { Xavier } & 2016 & \text { cohort } & \text { NOS } & 9\end{array}$

Guangfeng 2017

cohort NOS 8 high

cohort NOS 8 high

NOS: Newcastle-Ottawa quality assessment scale, RCT: Random Clinical Trails, iCAHE: The International Center for Allied Health Evidence, ARRIVE: Animal Research: Reporting in Vivo Experiments

cell $[20][23]$.

\subsection{Animal Experiments Results}

There were more than ten researches illustrated that stem cells could repair uterine endometrium in animal models during the recent 10 years [24]. Here, we conclude four typical articles among them to illustrate the stem cells application for animal models.

According to Sevtap and Beril [25], they have designed the experiment to evaluate the effects of stem cells to induce endometrial proliferation and angi- 
ogenesis on Asherman's Syndrome. This research resulted that the amount of fibrosis, vascularisation, inflammation and immune histochemical staining with vascular endothelial growth factor (VEGF), proliferating cell nuclear antigen (PCNA) and Ki-67 were evaluated in the uterine tissues. After mesenchymal stem cells (MSCs) therapy; fibrosis in mice uterine decreased but vascularisation and immune histochemical staining increased in the experimental side. This study also concluded that stem cells and estrogen were an extremely useful choose to induce regeneration of endometrium in Asherman Syndrome therapy. Similarly, Feryal Alawadhi et al. [26] Jianmei Wang et al. [27] and Yang et al. [28] conducted research that bone marrow-derived mesenchymal stem cells (BMSCs) were injected to adult female albino rats with uterine damage. They were observed that BMSCs transplantation was an original treatment for Asherman's Syndrome and may also be helpful to prevent Asherman's Syndrome after uterine injury.

The other researchers completed the animal experiments on rat model of IUAs and stem cell therapy for them, which reported that stem cells transplantation was a potential novel treatment for Asherman's Syndrome and may also be useful to prevent Asherman's Syndrome after uterine injury syndrome [15] [29] [30] [31].

\subsection{Stem Cell Application in Human IUAs: Meta-Analysis}

In recent ten years, there are several articles focusing on stem cells therapy in intrauterine adhesions and we have found five articles of human which are single arm studies focusing on this objection. Thus, we do the meta-analysis depending on them by software of meta-analyst [32] [33] [34] [35] [36].

Figure 2 shows the forest plots of age in the five studies which use random effect model because of $P=0.012$. The figure results that the weight mean difference is $33.765 \%$ and $95 \%$ Confidence Interval (95\% CI) is 33.330 to 34.201 .

Figure 3 shows that the endometrial thickness before stem cells treatment in these studies. And the weight mean difference (WMD) is 3.66 and $95 \% \mathrm{CI}$ is 2.599 to 4.620 , which results from random effect model by $\mathrm{P}<0.001$. Figure 4
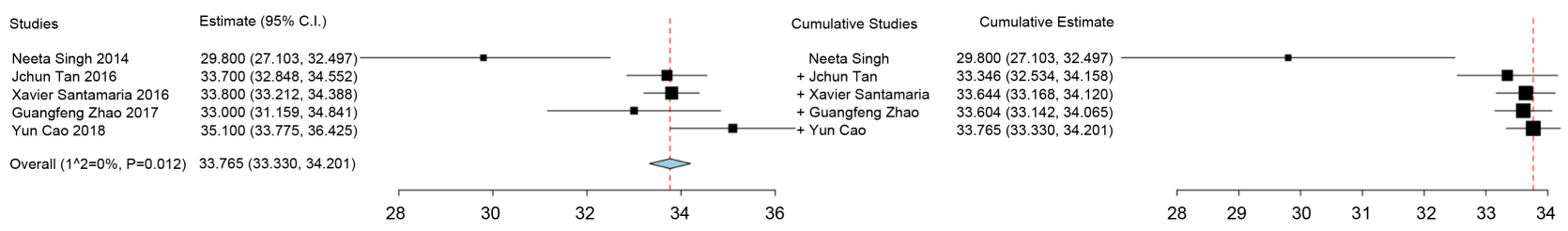

Figure 2. Forest plot of age.
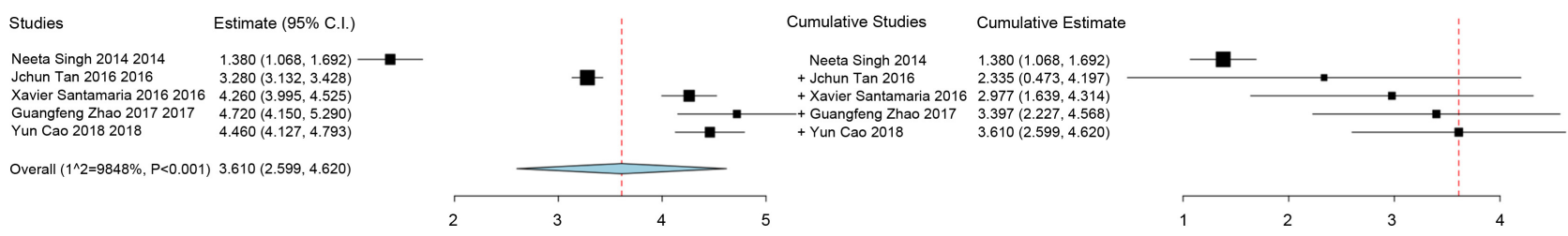

Figure 3. Forest plots of the endometrial thickness before stem cells treatment. 


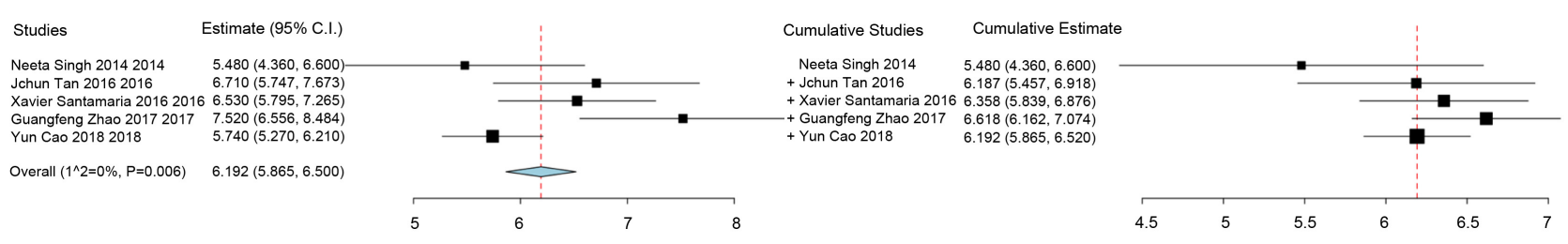

Figure 4. Forest plots of the endometrial thickness after stem cells treatment.

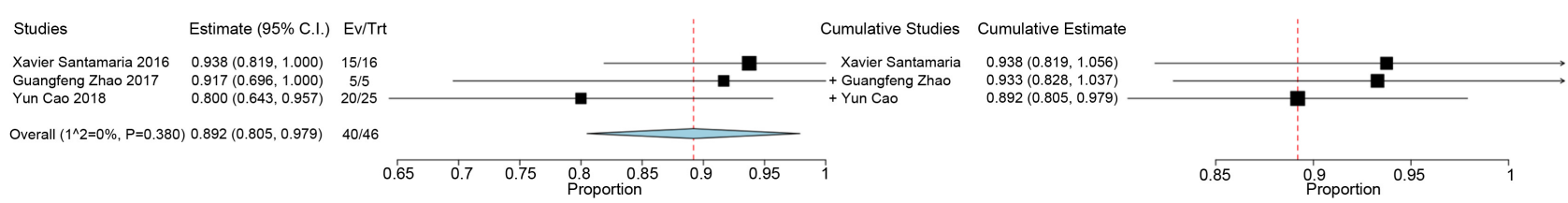

Figure 5. Forest plots of the improvement under hysteroscopy after stem cell therapy.

shows that the endometrial thickness after stem cells treatment. In which, the WMD is 6.192 and $95 \% \mathrm{CI}$ is 5.865 to 6.520 , which also results from random effect model by $\mathrm{P}=0.006$. Figure 5 illustrates that the improvement under hysteroscopy after stem cell therapy, but only three studies undergo it. And the forest plot shows that the estimated odd ratio is 0.892 (95\% CI: 0.805, 0.907) resulting from fixed effect model by $\mathrm{P}=0.3800$.

\section{Discussion}

Along with development and progression of IUAs, fibrotic tissues gradually covered or replaced the normal endometrium and promoted the formation of IUAs. And inflammatory factor TGF- $\beta$ has demonstrated to be a central mediator of the fibrotic response. Currently, Smad3 protein proves to an important signal transduction molecule that induces the activation of TGF- $\beta$ and the binding of TGF with receptors to the signal transduce from the cytoplasm to the nucleus. Through the TGF/Smad3 pathway, collagen synthesis and extracellular matrix precipitates are increased, promoting the formation of tissue fiber scar [23]. Activation and abnormal expression of TGF- $\beta 1$ can inhibit the expression of Matrix Metalloproteinase-9 (MMP-9), promote the expression of Tissue Inhibitor of Matrix Metalloproteinases-1 (TIMP-1), reduce the activity of proteolytic enzyme, then promote the formation of Extracellular Matrix (ECM) but not easy to be degraded, leading to the transformation of fibroblasts into myofibroblasts, and promote wound contraction [19]. The process of the pathogenesis of IUAs is complicated, other studies showed that the expression of MMP-9 and Nuclear Factor- $\mathrm{kB}(\mathrm{NF}-\kappa \mathrm{B})$ miRNA are also significantly higher in the endometrial sample from intrauterine adhesion compared to normal endometrial controls. Furthermore, the specific mechanism needs to be investigated [37] [38].

Although a couple of experiments have demonstrated the safety of stem cells transplantation as a therapeutic strategy for IUAs, the capability of self-renew of stem cell and the up-regulation of anti-inflammatory may induce uncontrolled cell growth and tumorigenesis.

As human clinical experiments result, we found that the age of IUAs under 
stem cells is about 33 years in four studies but one research which was written by Neeta Singh, included patients much younger than others (29.8). However, this study just integrated 6 cases that could not change the results significantly because of less weight. Thus, the bias of age is less. In addition, the endometrial thickness $(3.61 \mathrm{~mm})$ under ultrasound before treatment is rather thinner than normal ones (more than $5 \mathrm{~mm}$ ), which may be the main reason for amenorrhea and infertility. Then, after stem cell therapy including intrauterine injection and vein injection, the thickness of endometrial $(6.192 \mathrm{~mm})$ is improved significantly. However, the ultrasound could not be the best standard for evaluating the effectiveness of therapy depending on the guideline. Three of them finish hysteroscopy after stem cell therapy and 40 amongst 46 patients in these studies get improved from severe IUAs to normal endometrial or moderate IUAs. Also, the improving symptoms could be the evaluation like normal menstruation, pregnancy and delivery. Depending on Xavier Santamaria study more than $50 \%$ patient pregnant and $16 \%$ patients got babies in full-term, as well as, 4 patients and 1 patient in study from Zhao et al. are reported to full-term and premature labor in 28 weeks(twins) respectively. Thus, in clinical trial reports, we conclude that stem cell could be a new therapeutic schedule for IUAs.

However, all these researches are single-arm studies without control groups for comparison because it may be difficult for clinic to finish comparing with other therapy. Furthermore, we can develop the stem cell therapy treating IUAs for more patients and implement multi-center clinical study and Random Clinical Tests (RCTs).

\section{Acknowledgements}

We acknowledge the support of Beijing Hospital, National Center of Gerontology, National Cancer Center and Institute of Geriatric Medicine, Chinese Academy of Medical Sciences, China. This work was supported by the Beijing Dongcheng Department of Science, Technology, and Information (BJ-2019-103 to Shaowei Wang). The authors in this work, including Sichen Zhang, Ying Mao, Shaowei Wang, Huiwen Zhang, Min Ma, Xingbo Long, declare no competing interests. There is not necessary of ethical approval.

\section{Conflicts of Interest}

The authors declare no conflicts of interest regarding the publication of this paper.

\section{References}

[1] (1988) The American Fertility Society Classifications of Adnexal Adhesions, Distal Tubal Occlusion, Tubal Occlusion Secondary to Tubal Ligation, Tubal Pregnancies, Mullerian Anomalies and Intrauterine Adhesions. Fertility and Sterility, 49, 944955. https://doi.org/10.1016/S0015-0282(16)59942-7

[2] Asherman, J.G. (1950) Traumatic Intra-Uterine Adhesions. The Journal of Obstetrics and Gynaecology of the British Empire, 57, 892-896.

https://doi.org/10.1111/j.1471-0528.1950.tb06053.x 
[3] Valle, R.F. and Sciarra, J.J. (1988) Intrauterine Adhesions: Hysteroscopic Diagnosis, Classification, Treatment, and Reproductive Outcome. American Journal of Obstetrics and Gynecology, 158, 1459-1470.

https://doi.org/10.1016/0002-9378(88)90382-1

[4] (2017) AAGL Practice Report: Practice Guidelines on Intrauterine Adhesions Developed in Collaboration with the European Society of Gynaecological Endoscopy (ESGE). Journal of Minimally Invasive Gynecology, 24, 695-705. https://doi.org/10.1016/j.jmig.2016.11.008

[5] Yu, X., et al. (2016) The Incidence of Post-Operative Adhesion Following Transection of Uterine Septum: A Cohort Study Comparing Three Different Adjuvant Therapies. European Journal of Obstetrics, Gynecology, and Reproductive Biology, 201, 61-64. https://doi.org/10.1016/j.ejogrb.2016.01.039

[6] Deans, R. and Abbott, J. (2010) Review of Intrauterine Adhesions. Journal of Minimally Invasive Gynecology, 17, 555-569. https://doi.org/10.1016/j.jmig.2010.04.016

[7] Conforti, A., Alviggi, C., Mollo, A., De Placido, G. and Magos, A. (2013) The Management of Asherman Syndrome: A Review of Literature. Reproductive Biology and Endocrinology, 11, 118. https://doi.org/10.1186/1477-7827-11-118

[8] Salazar, C.A., Isaacson, K. and Morris, S. (2017) A Comprehensive Review of Asherman's Syndrome: Causes, Symptoms and Treatment Options. Current Opinion in Obstetrics \& Gynecology, 29, 249-256.

https://doi.org/10.1097/GCO.0000000000000378

[9] (2010) AAGL Practice Report: Practice Guidelines for Management of Intrauterine Synechiae. Journal of Minimally Invasive Gynecology, 17, 1-7.

https://doi.org/10.1016/j.jmig.2009.10.009

[10] Healy, M.W., Schexnayder, B., Connell, M.T., Terry, N., DeCherney, A.H., Csokmay, J.M., Yauger, B.J. and Hill, M.J. (2016) Intrauterine Adhesion Prevention after Hysteroscopy: A Systematic Review and Meta-Analysis. American Journal of $\mathrm{Ob}$ stetrics and Gynecology, 215, 267-275.e267.

https://doi.org/10.1016/j.ajog.2016.05.001

[11] Liu, A.Z., Zhao, H.G., Gao, Y., Liu, M. and Guo, B.Z. (2016) Effectiveness of Estrogen Treatment before Transcervical Resection of Adhesions on Moderate and Severe Uterine Adhesion Patients. Gynecological Endocrinology, 32, 737-740. https://doi.org/10.3109/09513590.2016.1160375

[12] Chi, Y., He, P., Lei, L., Lan, Y., Hu, J., Meng, Y. and Hu, L. (2018) Transdermal Estrogen Gel and Oral Aspirin Combination Therapy Improves Fertility Prognosis via the Promotion of Endometrial Receptivity in Moderate to Severe Intrauterine Adhesion. Molecular Medicine Reports, 17, 6337-6344.

https://doi.org/10.3892/mmr.2018.8685

[13] Hooker, A.B., de Leeuw, R., van de Ven, P.M., Bakkum, E.A., Thurkow, A.L., Vogel, N.E.A., van Vliet, H., Bongers, M.Y., Emanuel, M.H., Verdonkschot, A.E.M., Brolmann, H.A.M. and Huirne, J.A.F. (2017) Prevalence of Intrauterine Adhesions after the Application of Hyaluronic Acid Gel after Dilatation and Curettage in Women with at Least One Previous Curettage: Short-Term Outcomes of a Multicenter, Prospective Randomized Controlled Trial. Fertility and Sterility, 107, 1223-1231, e1223. https://doi.org/10.1016/j.fertnstert.2017.02.113

[14] Liu, H., Xu, Y., Yi, N. and Yi, W. (2018) Efficacy and Safety of Hyaluronic Acid Gel for the Prevention of Intrauterine Adhesion: A Meta-Analysis of Randomized Clinical Trials. Gynecologic and Obstetric Investigation, 83, 227-233. https://doi.org/10.1159/000486674

[15] Liu, Y., Tal, R., Pluchino, N., Mamillapalli, R. and Taylor, H.S. (2018) Systemic 
Administration of Bone Marrow-Derived Cells Leads to Better Uterine Engraftment than Use of Uterine-Derived Cells or Local Injection. Journal of Cellular and Molecular Medicine, 22, 67-76. https://doi.org/10.1111/jcmm.13294

[16] Gargett, C.E. and Ye, L. (2012) Endometrial Reconstruction from Stem Cells. Fertility and Sterility, 98, 11-20. https://doi.org/10.1016/j.fertnstert.2012.05.004

[17] Queckborner, S., Davies, L.C., von Grothusen, C., Santamaria, X., Simon, C. and Gemzell-Danielsson, K. (2019) Cellular Therapies for the Endometrium: An Update. Acta Obstetricia et Gynecologica Scandinavica, 98, 672-677. https://doi.org/10.1111/aogs.13598

[18] Hu, J., Zeng, B., Jiang, X., Hu, L., Meng, Y., Zhu, Y. and Mao, M. (2015) The Expression of Marker for Endometrial Stem Cell and Fibrosis Was Increased in Intrauterine Adhesious. International Journal of Clinical and Experimental Pathology, 8, 1525-1534.

[19] Ebrahim, N., Mostafa, O., El Dosoky, R.E., Ahmed, I.A., Saad, A.S., Mostafa, A., Sabry, D., Ibrahim, K.A. and Farid, A.S. (2018) Human Mesenchymal Stem Cell-Derived Extracellular Vesicles/Estrogen Combined Therapy Safely Ameliorates Experimentally Induced Intrauterine Adhesions in a Female Rat Model. Stem Cell Research \& Therapy, 9, 175. https://doi.org/10.1186/s13287-018-0924-Z

[20] Sahin Ersoy, G., Zolbin, M.M., Cosar, E., Moridi, I., Mamillapalli, R. and Taylor, H.S. (2017) CXCL12 Promotes Stem Cell Recruitment and Uterine Repair after Injury in Asherman's Syndrome, Molecular Therapy. Methods \& Clinical Development, 4, 169-177. https://doi.org/10.1016/j.omtm.2017.01.001

[21] Liu, D., Ha, C., Zhang, X., Zhang, Z. and Liu, P. (2013) Molecular Implication of ADAM-15 and -17 in Intrauterine Adhesions. European Journal of Obstetrics, Gynecology, and Reproductive Biology, 170, 264-269.

https://doi.org/10.1016/j.ejogrb.2013.06.036

[22] Zhou, Q., Wu, X., Hu, J. and Yuan, R. (2018) Abnormal Expression of Fibrosis Markers, Estrogen Receptor Alpha and Stromal Derived Factor1/Chemokine (CXC Motif) receptor4 Axis in Intrauterine Adhesions. International Journal of Molecular Medicine, 42, 81-90. https://doi.org/10.3892/ijmm.2018.3586

[23] Salma, U., Xue, M., Ali Sheikh, M.S., Guan, X., Xu, B., Zhang, A., Huang, L. and Xu, D. (2016) Role of Transforming Growth Factor-betal and Smads Signaling Pathway in Intrauterine Adhesion. Mediators of Inflammation, 2016, Article ID: 4158287. https://doi.org/10.1155/2016/4158287

[24] Sabry, D., Mostafa, A., Marzouk, S., Ibrahim, W., Ali, H.H.M., Hassan, A. and Shamaa, A. (2017) Neupogen and Mesenchymal Stem Cells Are the Novel Therapeutic Agents in Regeneration of Induced Endometrial Fibrosis in Experimental Rats. Bioscience Reports, 37, BSR20170794. https://doi.org/10.1042/BSR20170794

[25] Kilic, S., Yuksel, B., Pinarli, F., Albayrak, A., Boztok, B. and Delibasi, T. (2014) Effect of Stem Cell Application on Asherman Syndrome, an Experimental Rat Model. Journal of Assisted Reproduction and Genetics, 31, 975-982. https://doi.org/10.1007/s10815-014-0268-2

[26] Alawadhi, F., Du, H., Cakmak, H. and Taylor, H.S. (2014) Bone Marrow-Derived Stem Cell (BMDSC) Transplantation Improves Fertility in a Murine Model of Asherman's Syndrome. PLoS ONE, 9, e96662. https://doi.org/10.1371/journal.pone.0096662

[27] Wang, J., Ju, B., Pan, C., Gu, Y., Zhang, Y., Sun, L., Zhang, B. and Zhang, Y. (2016) Application of Bone Marrow-Derived Mesenchymal Stem Cells in the Treatment of Intrauterine Adhesions in Rats. Cellular Physiology and Biochemistry. International Journal of Experimental Cellular Physiology, Biochemistry, and Pharmacology, 39, 
1553-1560. https://doi.org/10.1159/000447857

[28] Yang, H., Wu, S., Feng, R., Huang, J., Liu, L., Liu, F. and Chen, Y. (2017) Vitamin C plus Hydrogel Facilitates Bone Marrow Stromal Cell-Mediated Endometrium Regeneration in Rats. Stem Cell Research \& Therapy, 8, 267. https://doi.org/10.1186/s13287-017-0718-8

[29] Zheng, S.X., Wang, J., Wang, X.L., Ali, A., Wu, L.M. and Liu, Y.S. (2018) Feasibility Analysis of Treating Severe Intrauterine Adhesions by Transplanting Menstrual Blood-Derived Stem Cells. International Journal of Molecular Medicine, 41, 22012212. https://doi.org/10.3892/ijmm.2018.3415

[30] Zhang, S., Li, P., Yuan, Z. and Tan, J. (2019) Platelet-Rich Plasma Improves Therapeutic Effects of Menstrual Blood-Derived Stromal Cells in Rat Model of Intrauterine Adhesion. Stem Cell Research \& Therapy, 10, 61. https://doi.org/10.1186/s13287-019-1155-7

[31] Gan, L., Duan, H., Xu, Q., Tang, Y.Q., Li, J.J., Sun, F.Q. and Wang, S. (2017) Human Amniotic Mesenchymal Stromal Cell Transplantation Improves Endometrial Regeneration in Rodent Models of Intrauterine Adhesions. Cytotherapy, 19, $603-$ 616. https://doi.org/10.1016/j.jcyt.2017.02.003

[32] Tan, J., Li, P., Wang, Q., Li, Y., Li, X., Zhao, D., Xu, X. and Kong, L. (2016) Autologous Menstrual Blood-Derived Stromal Cells Transplantation for Severe Asherman's Syndrome. Human Reproduction (Oxford, England), 31, 2723-2729. https://doi.org/10.1093/humrep/dew235

[33] Santamaria, X., Cabanillas, S., Cervello, I., Arbona, C., Raga, F., Ferro, J., Palmero, J., Remohi, J., Pellicer, A. and Simon, C. (2016) Autologous Cell Therapy with CD133+ Bone Marrow-Derived Stem Cells for Refractory Asherman's Syndrome and Endometrial Atrophy: A Pilot Cohort Study. Human Reproduction (Oxford, England), 31, 1087-1096. https://doi.org/10.1093/humrep/dew042

[34] Zhao, G., Cao, Y., Zhu, X., Tang, X., Ding, L., Sun, H., Li, J., Li, X., Dai, C., Ru, T., Zhu, H., Lu, J., Lin, C., Wang, J., Yan, G., Wang, H., Wang, L., Dai, Y., Wang, B., Li, R., Dai, J., Zhou, Y. and Hu, Y. (2017) Transplantation of Collagen Scaffold with Autologous Bone Marrow Mononuclear Cells Promotes Functional Endometrium Reconstruction via Downregulating DeltaNp63 Expression in Asherman's Syndrome. Science China Life Sciences, 60, 404-416. https://doi.org/10.1007/s11427-016-0328-y

[35] Cao, Y., Sun, H., Zhu, H., Zhu, X., Tang, X., Yan, G., Wang, J., Bai, D., Wang, J., Wang, L., Zhou, Q., Wang, H., Dai, C., Ding, L., Xu, B., Zhou, Y., Hao, J., Dai, J. and $\mathrm{Hu}, \mathrm{Y}$. (2018) Allogeneic Cell Therapy Using Umbilical Cord MSCs on Collagen Scaffolds for Patients with Recurrent Uterine Adhesion: A Phase I Clinical Trial. Stem Cell Research \& Therapy, 9, 192.

https://doi.org/10.1186/s13287-018-0904-3

[36] Singh, N., Mohanty, S., Seth, T., Shankar, M., Bhaskaran, S. and Dharmendra, S. (2014) Autologous Stem Cell Transplantation in Refractory Asherman's Syndrome: A Novel Cell Based Therapy. Journal of Human Reproductive Sciences, 7, 93-98. https://doi.org/10.4103/0974-1208.138864

[37] Wang, X., Ma, N., Sun, Q., Huang, C., Liu, Y. and Luo, X. (2017) Elevated NF-kappaB Signaling in Asherman Syndrome Patients and Animal Models. Oncotarget, 8, 15399-15406. https://doi.org/10.18632/oncotarget.14853

[38] Xue, X., Chen, Q., Zhao, G., Zhao, J.Y., Duan, Z. and Zheng, P.S. (2015) The Overexpression of TGF-Beta and CCN2 in Intrauterine Adhesions Involves the NF-kappaB Signaling Pathway. PLoS ONE, 10, e0146159. https://doi.org/10.1371/journal.pone.0146159 


\section{Abbreviation}

IUAs = Intrauterine Adhesions.

AS = Asherman's Syndrome.

MRI = Magnetic Resonance Imaging.

HSG $=$ Hysterosalpingography.

ESGE = European Society of Gynecological Endoscopy.

$\mathrm{ESH}=$ European Society for Hysteroscopy.

AFS $=$ American Fertility Society.

AAGL $=$ American Association of Gynecologic Laparoscopists.

MenSCs $=$ Menstrual blood derived Stromal Cells.

$\mathrm{UC}=$ Umbilical Cord.

MSCs = Mesenchymal Stromal Cells.

BMMNCs = Bone Marrow derived Mononuclear Cells.

NOS = Newcastle-Ottawa quality assessment scale.

$\mathrm{WMD}=$ Weight Mean Difference.

$\mathrm{OR}=$ Odds Ratio.

$\mathrm{CI}=$ Confidence Interval.

TGF- $\beta=$ Transforming Growth Factors $-\beta$.

TNF- $\alpha=$ Tumor Necrosis Factor- $\alpha$.

VEGF = Vascular Endothelial Growth Factor.

UCMSCs-EVs = Extracellular Vesicles derived from human Umbilical Cord Mesenchymal Stem Cells.

$\mathrm{ER} \alpha=$ Estrogen Receptor $\alpha$.

SDF-1/CXCR-4 = Stromal Derived Factor/Chemokine Receptor type 4.

bFGF $=$ Fibroblast Growth Factor.

$\mathrm{IL}=$ Interleukin.

VEGF = Vascular Endothelial Growth Factor.

PCNA = Proliferating Cell Nuclear Antigen.

MMP-9 = Matrix Metalloproteinase-9.

TIMP-1 = Tissue Inhibitor of Matrix Metalloproteinases-1.

$\mathrm{ECM}=$ Extracellular Matrix.

$\mathrm{NF}-\kappa \mathrm{B}=$ Nuclear Factor $-\kappa \mathrm{B}$.

RCTs $=$ Random Clinical Tests 